\title{
Surgical treatment of mandibular fracture resulting from first molar extraction: case
}

\section{report}

\author{
Manejo cirúrgico de fratura mandibular decorrente de exodontia de primeiro molar: relato de caso \\ Tratamiento quirúrgico de la fractura mandibular resultante de la extracción del primer molar:
}

relato de caso

Received: 09/22/2021 | Reviewed: 10/01/2021 | Accept: 10/05/2021| Published: 10/09/2021

Monique Gonçalves da Costa ORCID: https://orcid.org/0000-0002-0867-1736

Universidade Estadual Paulista, Brasil

E-mail: moniquegc30@hotmail.com

Anderson Maikon de Souza Santos

ORCID: https://orcid.org/0000-0001-9371-9417

Universidade Estadual Paulista, Brasil

E-mail: ams.santos@unesp.br

Mirela Caroline Silva

ORCID: https://orcid.org/0000-0002-9455-3807

Universidade Estadual Paulista, Brasil

E-mail: mirela_carol12@hotmail.com

Tiburtino José de Lima Neto

ORCID: https://orcid.org/0000-0002-8297-4057

Universidade Estadual Paulista, Brasil

E-mail: tiburtinoneto@hotmail.com

Eduardo Dallazen

ORCID: https://orcid.org/0000-0002-7994-5634

Universidade Estadual Paulista, Brasil

E-mail: dallazen.d@gmail.com

Mileni Buzo Souza

ORCID: https://orcid.org/0000-0001-5354-5539 Universidade Estadual Paulista, Brasil

E-mail: mileni.buzo@unesp.br

Eduardo Hochuli-Vieira

ORCID: https://orcid.org/0000-0003-4040-9313 Universidade Estadual Paulista, Brasil E-mail: eduardo.hochuli@unesp.br

Leonardo Perez Faverani

ORCID: https://orcid.org/0000-0003-2249-3048 Universidade Estadual Paulista, Brasil E-mail: leonardo.faverani@unesp.br

\begin{abstract}
Extraction is one of the most common procedures performed by dental surgeons in their daily clinical practice. Among the trans and postoperative complications associated with this procedure can be mentioned the occurrence of trismus, infections, edema, alveolitis, paresthesia or fractures. The purpose of this study was to report a clinical case of a mandibular fracture associated with first molar extraction, approaching its main risk factors and treatment. Patient JSS, 24 years old, female, was referred to the service of Maxillofacial Surgery due to complications resulted from the extraction of element 36. On physical examination, was observed the presence of fragment mobility, communication of bone tissue with the oral environment and pain complaint was reported by the patient. Computed tomography showed the presence of a fracture in the region of the mandibular body on the left side. The planned surgical proposal was the intraoral debridement of bone fragments, extraoral access in the base of the mandible, fixation of the fracture with plate 2.4 and intraoral and extraoral access suture. During the surgical procedure, it is of great importance that the dental surgeon be aware to the signals emitted by the patient, such as clicks associated with severe pain, profuse bleeding or crackling as these symptoms may be the result of mandibular fracture. When any of these signs are found during the operation, the professional must investigate the occurrence of a possible fracture. It is concluded that in addition to performing a good preoperative evaluation, the dental surgeon must carry out a correct planning of the surgical act based on the basic principles of the surgical technique.
\end{abstract}

Keywords: Surgery oral; Intraoperative complications; Fracture fixation; Mandible. 


\begin{abstract}
Resumo
A exodontia é um dos procedimentos mais realizados por cirurgiões dentistas em sua prática clínica cotidiana. Dentre as complicações trans e pós-operatórias associadas a esse procedimento pode-se mencionar a ocorrência de trismo, infecções, edema, alveolites, paretesia ou fraturas. Objetivou-se com o presente trabalho relatar um caso clínico de uma fratura mandibular associada à exodontia de primeiro molar, abordando seus principais fatores de risco e tratamento. Paciente J.S.S, 24 anos, sexo feminino, foi encaminhada ao serviço de Cirurgia Bucomaxilofacial devido a complicações decorrentes da exodontia do elemento 36. Ao exame físico, observou-se a presença de mobilidade de fragmento, comunicação de tecido ósseo com o meio bucal e queixa álgica relatada pela paciente. A tomografia computadorizada evidenciou a presença de fratura na região de corpo mandibular do lado esquerdo. A proposta cirúrgica planejada foi a debridamento intrabucal de fragmentos ósseos, acesso extrabucal na região de base da mandíbula, fixação da fratura com placa 2.4 e sutura intrabucal e extrabucal do acesso. Durante o procedimento cirúrgico, é de grande importância que o cirurgião dentista esteja atento aos sinais emitidos pelo paciente, como estalidos associados à dor intensa, sangramento abundante ou crepitação pois esses sintomas podem ser resultado de fratura mandibular. Quando algum desses sinais é encontrado durante o ato operatório, o profissional deve investigar a ocorrência de uma possível fratura. Conclui-se que além da realização de uma boa avaliação pré-operatória, o cirurgião dentista deve realizar um correto planejamento do ato cirúrgico fundamentando-se nos princípios básicos da técnica cirúrgica.
\end{abstract}

Palavras-chave: Cirurgia bucal; Complicações intraoperatórias; Fixação de fratura; Mandíbula.

\title{
Resumen
}

La exodoncia es uno de los procedimientos más habituales que realizan los cirujanos dentistas en su práctica clínica diaria. Entre las complicaciones trans y postoperatorias asociadas a este procedimiento, se pueden mencionar la aparición de trismus, infecciones, edemas, alveolitis, pareteia o fracturas. El objetivo de este estudio fue reportar un caso clínico de fractura mandibular asociada a la extracción del primer molar, abordando sus principales factores de riesgo y tratamiento. Paciente JSS, 24 años, mujer, fue remitida al servicio de Cirugía Maxilofacial por complicaciones derivadas de la extracción del elemento 36. Al examen físico se observó presencia de movilidad de fragmentos, comunicación del tejido óseo con el medio bucal y queja. dolor informado por el paciente. La tomografía computarizada mostró la presencia de una fractura en la región del cuerpo mandibular del lado izquierdo. La propuesta quirúrgica planificada fue desbridamiento intraoral de fragmentos óseos, acceso extraoral en la base de la mandíbula, fijación de la fractura con placa 2.4 y sutura de acceso intraoral y extraoral. Durante el procedimiento quirúrgico, es de gran importancia que el cirujano dental esté atento a las señales que emite el paciente, tales como clics asociados a dolor severo, sangrado profuso o crepitaciones ya que estos síntomas pueden ser el resultado de una fractura mandibular. Cuando se encuentre alguno de estos signos durante la operación, el profesional deberá investigar la ocurrencia de una posible fractura. Se concluye que además de realizar una buena evaluación preoperatoria, el cirujano dentista debe realizar una correcta planificación del acto quirúrgico basado en los principios básicos de la técnica quirúrgica.

Palabras clave: Cirugía bucal; Complicaciones intraoperatorias; Fijación de fractura; Mandíbula.

\section{Introduction}

Extraction is one of the procedures most performed by dentists in their clinical routine. It is a surgical intervention indicated for cases of erupted or impacted teeth, and for the removal of dental elements for orthodontic or prosthetic reasons (Bazarin \& Oliveira, 2018; Almeida \& Pereira, 2020). Among the trans and postoperative complications associated with this procedure can be mentioned the occurrence of trismus, edema, alveolitis, oral-sinusal communication, infections, hemorrhages, paresthesia, and in rare situations, mandibular or maxillary fracture (Xu, Teng, Jin, Lu \& Zhang, 2014; Bazarin \& Oliveira, 2018; Silva, Maranhão Filho, Alencar, De Bortoli \& Vasconcelos, 2019; Botelho, de Oliveira Dantas, Pimentel \& Correa, 2020).

Complications due to extractions are resulting from failure in surgical planning, lack of knowledge about anatomical structures or use of improper techniques, in addition to the application of excessive force and use of inadequate instruments (Bazarin \& Oliveira, 2018; Botelho et al., 2020). Such intercurrences are multifactorial and are also correlated with local and systemic factors that include tooth position, age, systemic condition and patient habits (Botelho et al., 2020; dos Santos Silva, Silveira, de Araujo Andrade, Franco, \& Silva, 2017). The occurrence of mandibular fractures, although rare with an incidence from $0.0034 \%$ to $0.0075 \%$ in tooth extractions, requires special attention to be avoided (Blanski et al., 2012). In many situations, lower arch extractions require the performance of osteotomies and odontosection with surgical drills and the use of 
levers. When these are performed inappropriately, they can generate fragility of the mandibular bone, increasing the possibility of fracture occurring during the trans- or postoperative period (de Lima, Figueiredo, Momesso, de Queiroz, \& Faverani, 2017).

The mandible is the only mobile bone of the facial skeleton, presenting a biginglimoarthrodial joint, that is, forces exerted on one side can affect the opposite side. In addition to presenting complex biomechanics, this structure has the function of supporting masticatory loads and providing resistance to all the muscles that are part of it. Considering its importance, fractures that affect this region must be repaired as soon as possible (Botelho et al., 2020; de Lima et al., 2017). After the occurrence of the fracture, patients present signs and symptoms that make correct chewing, speech and swallowing impossible and usually progress to an infectious condition when not adequately treated (Almeida, 2021; de Lima et al., 2017).

The main objective of the treatments for mandibular fractures is to restore the patient's functional occlusal and aesthetic (de Lima et al., 2017). In order to adequately treat mandibular fractures, it is necessary to take into account the principles that guide traumatology: reduction, containment, immobilization and infection control. Interventions can be performed in two ways: for cases with lighter changes, conservative treatment is chosen through dietary guidance, maxillomandibular block and therapy with elastic bands. In more severe cases, surgical intervention under general anesthesia is recommended for intraoral or extraoral access and fixation with plates and screws. The choice of the best approach should only be made after a precise diagnosis has been defined and needs to take into account the nature of the fracture, the number and condition of dental morphology, in addition to the possible factors that may interfere with the repair (de Lima et al., 2017; Soares, de Souza Carvalho, de Resende, \& Gomes, 2019).

The aim of this article is to report a clinical case of mandibular fracture associated with first molar extraction, approaching its main risk factors and choosing the ideal therapeutic approach.

\section{Methodology}

This article presents a qualitative and descriptive clinical case study. According to the literature, studies of this nature are characterized by explaining a certain topic and studying it in detail, through access to medical records, clinical examination, laboratory and imaging tests available, with the researcher being the main instrument (Pereira, Shitsuka, Parreira, \& Shitsuka, 2018). The survey was carried out in databases such as PubMed and LILACS, with analysis of articles relevant to the subject of the study. As this is a case report, it was not necessary to submit and approve the Research Ethics Committee, but the patient agreed and authorized the use of images, clinical and radiographic data for educational purposes, signing the Informed Consent Form (TCLE). Furthermore, the present case was conducted in accordance with the ethical principles of the Declaration of Helsinki.

\section{Case Report}

Patient JSS, 24 years old, female, was referred to the Maxillofacial Surgery Service of the State Hospital for Emergency and Trauma due to complications resulting from excessive osteomy during extraction of element 36 . In the anamnesis, she denied having systemic comorbidities, smoker or alcoholic.

On physical examination, a slight limitation of the mouth opening was observed (Figure 1A) and the presence of fragment mobility and bone tissue communication with the oral environment in the posterior region of the mandible on the left side (Figure 1B). The patient complained of severe pain at the time of the exam. 
Figure 1: A- Mild limitation in the degree of mouth opening found in the physical examination. B- Intraoral clinical aspect showing area of exposure of bone tissue in the posterior region of the left mandible.

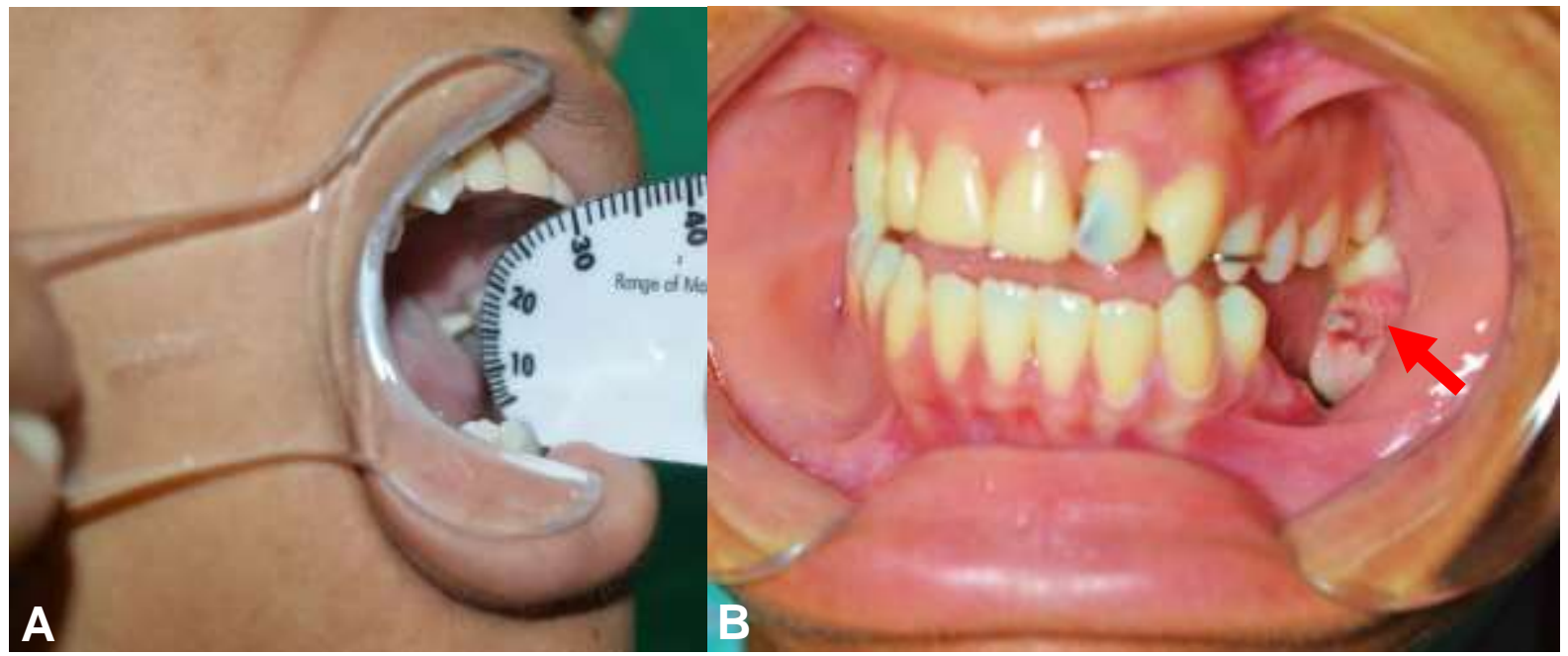

Source: Own authorship.

The first image shows the initial appearance of the patient in the clinical examination. Figure 1A demonstrates the performance of the exam to verify the degree of mouth opening, where a slight limitation was found. In $1 \mathrm{~B}$, the red arrow shows the extensive area of communication between the mandibular bone tissue and the oral environment.

After clinical examination, computed tomography was requested, which showed the presence of a complete fracture line in the region of the mandibular body extending to the base of the left side with fragment displacement (Figure 2 A and B).

Figure 2: A- Lateral view of the three-dimensional reconstruction of the computed tomography showing a fracture in the region of the mandibular body on the left side. B- Bottom view of the computed tomography $3 \mathrm{D}$ reconstruction showing the displacement of the bone fragment.

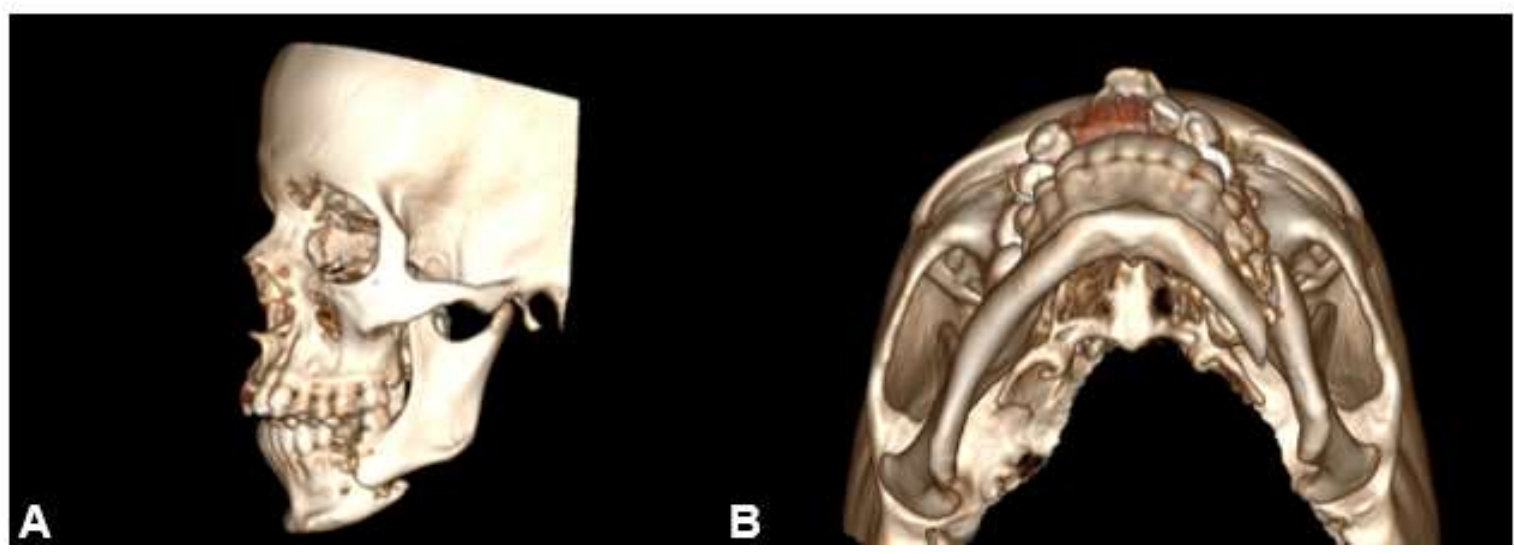

Source: Own authorship.

In image 2 , it is possible to verify, in the $3 \mathrm{D}$ reconstruction of the computed tomography, the position and extension of the fracture in question, as well as the displacement of the bone fragment.

The patient underwent a surgical procedure under general anesthesia for fracture fixation. Local antisepsis and preparation of the surgical field were performed. Then, the intraoral debridement of bone fragments was performed. An extraoral access was performed in the region of the base of the mandible on the left side, for fixation of the fracture with plates 
of the 2.4 system. Subsequently, extraoral suture of the access was performed by planes with 4-0 vicryl for the internal planes and 5-0 nylon for the skin. Finally, an intraoral suture with 4-0 vicryl was performed to close the bone defect resulting from the fracture and soft tissue (Figure 3).

Figure 3: A- Incision in the base of the mandible to access the area of interest B- Fixation of the fracture with system plate and screws $2.4 \mathrm{C}$ - Carrying out an intradermal suture in the extraoral region.

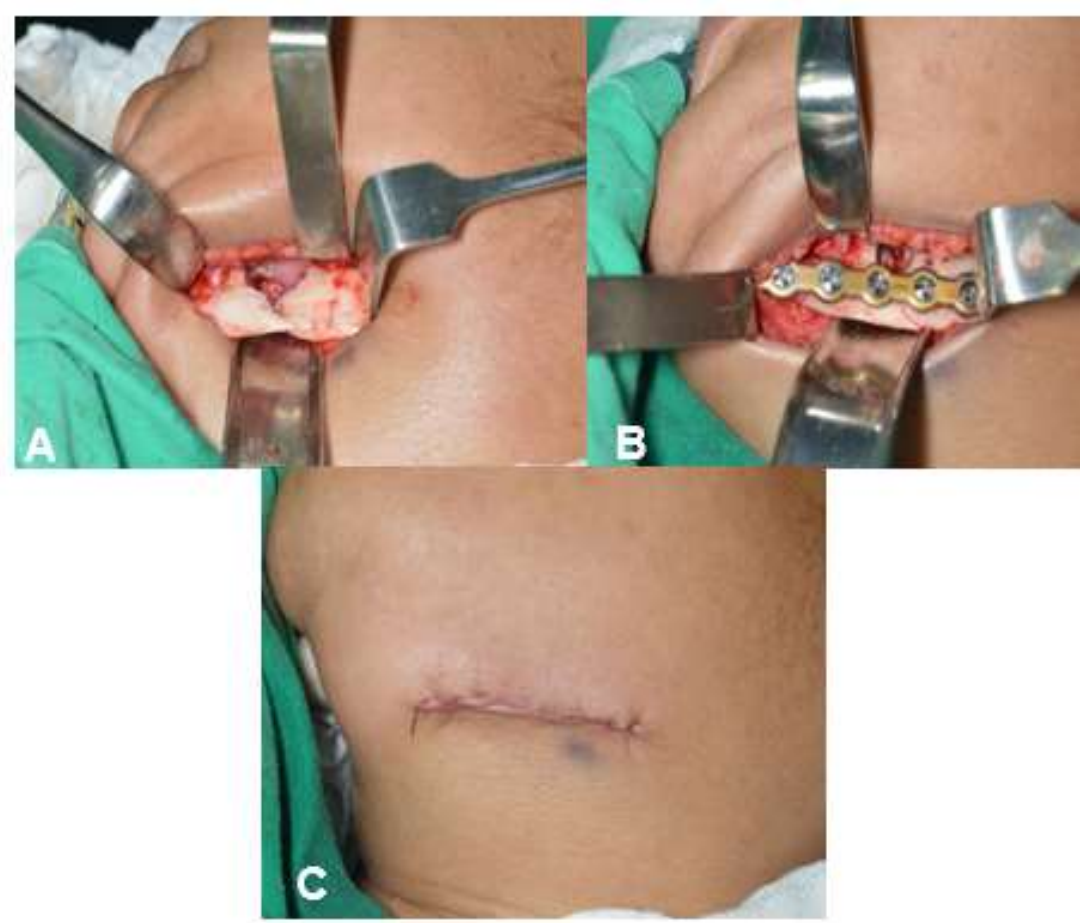

Source: Own authorship.

In Image 3 in $\mathrm{A}$, it is possible to observe the surgical access that was performed on the mandibular base; in B, it is possible to observe the fixation system already in position, promoting the union of the bone stumps. C shows the final extraoral appearance after performing the intradermal suture.

The patient was followed up for 1 year and a half, through clinical and radiographic evaluation, through which excellent bone repair, stable occlusion and reestablishment of mandibular movements were observed. (Figure 4). 
Figure 4: A- Postoperative radiographic follow-up of the patient. B- 3D reconstruction of postoperative computed tomography showing the success of osteosynthesis

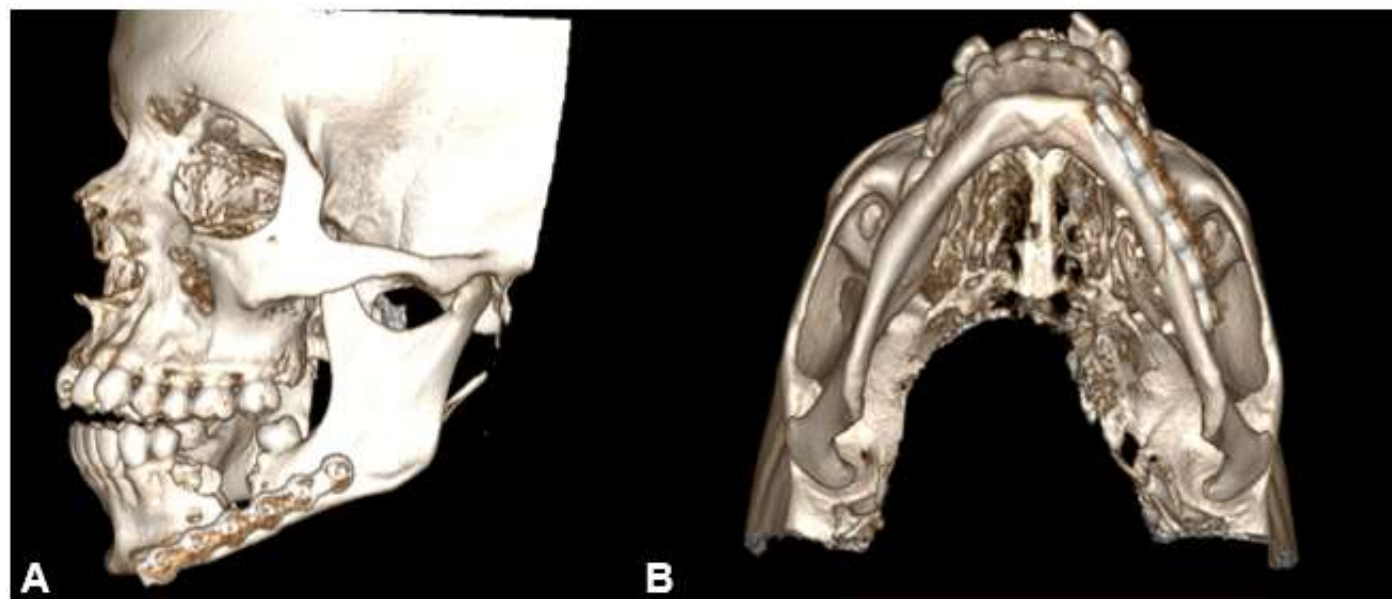

Source: Own authorship.

In image $4(\mathrm{~A}$ and $\mathrm{B})$ the success of the osteosynthesis procedure can be seen through the 3D reconstruction of the computed tomography, through fixation with plate and screws of the 2.4 system.

\section{Discussion}

Accidents and trans and postoperative complications are a reality in dental surgical procedures. The greater the complexity of the surgical technique used, the greater the chances of these adversities occurring. Among the various complications, mandibular fractures are described as rare complications that occur when the bone resistance force is overcome by forces acting on it (Blanski et al., 2012; Delantoni \& Antoniades, 2010; Xu et al., 2014). The mandible is the only mobile bone of the facial skeleton, presenting a zone of resistance and fragility and, according to its anatomy, some regions are more prone to the occurrence of fractures, such as: body (29.5\%), angle (27.3\%); condyle (21.1\%); symphysis (19.5\%); branch (2.4\%); and coronoid process (0.2\%) (Flandes, Dias, \& Junior, 2019).

The occurrence of mandibular fractures is multifactorial and can be associated with both local and systemic factors such as impacted or impacted teeth, osteogenesis imperfect, osteoporosis and other metabolic diseases that predispose to decreased bone density, teeth with ankylosis and pathological lesions or inflammatory diseases, as factors related to failure in surgical planning, lack of knowledge about anatomical structures or use of improper techniques, in addition to the application of excessive force and use of inadequate instruments (Bazarin \& Oliveira, 2018; Botelho et al., 2020). The literature reports that, among other factors, the exacerbated use of osteotomy contributes to the occurrence of mandibular fractures (Ishii et al., 2012; Blanski et al., 2013). In the case reported, the professional ended up performing excessive osteotomy leading to the weakening of the bone tissue and excessive force was used when removing the dental element, consequently leading to the occurrence of fracture in the region of the mandibular body, extending to the base of the left side.

With regard to the epidemiology of this type of intercurrence, the literature demonstrates that intraoperative mandibular fractures are more common in the age group of 16 to 45 years and differ from postoperative fractures, which are more common in the age group of 36 to 60 years old (Botelho et al., 2020; Ethunandan, Shanahan, \& Patel, 2012). It is also verified that intraoperative fractures are more common in women at a ratio of 1:1.3 and differ from the predominance of males in the postoperative period, which have a ratio of 3.9:1 (Alves Filho et al., 2019; Bachmann, Cáceres, Muñoz, \& Uribe, 2014; Ethunandan et al., 2012). These data corroborate the present case, since the patient in question was female and was in the 
aforementioned age group, thus demonstrating that, despite the predominance of postoperative fractures being in males, due to these not be careful with the recommendations, during the trans-operative period this complication ends up affecting female patients in a greater proportion, leading to the need for further studies to verify the relationship of these two factors.

To the dental surgeon responsible for performing the surgical procedure, the importance of care is highlighted due to the risk of intra- and postoperative complications. The professional must analyze the risks and benefits, in addition to the groups of people who need immediate attention for these types of interventions. The literature has shown that the prevalence of this complication has declined over time, which is justified by the greater ability of surgeons to detect more complex cases and to prepare themselves previously to prevent such accidents (Alves Filho et al., 2019; Botelho et al., 2020). Another important point is that during the surgical procedure, the professional must be aware of the signs expressed by the patient, such as crackling, excessive bleeding and clicking associated with intense pain. When any of these signs are found during the surgical procedure, it must be investigated, as they may be indicative of the occurrence of a fracture in the mandibular region (Blanski et al., 2012; Flandes et al., 2019). Considering its importance, fractures that affect this region must be repaired as soon as possible (Botelho et al., 2020; de Lima et al., 2017).

Regarding the treatment, the literature has addressed two modalities: open or closed. Choosing the most appropriate technique will depend on the fracture anatomy and the degree of displacement. Usually, the closed approach is recommended for slightly displaced condylar fractures or high fractures and it is a safer technique in general, as it reduces the chance of morbidity (de Lima et al., 2017). Fractures involving angle, branch and body regions will usually be surgically addressed, unless they are incomplete or non-displaced fracture traces, this type of approach is the most complex and invasive treatment. To carry out the reduction and internal fixation with the system of plates and screws, bioabsorbable plates or steel wire, it is necessary to properly classify the fracture, with those that present a single feature, with minimal displacement or absence of it, and presenting intact bone segments should be classified as simple (Hupp, Tucker, \& Ellis, 2013). Displaced fractures, with more than one line, with extensive osteotomies, present a large reduction of bone remnant should be classified as complex (de Lima et al., 2017; Miloro, Larsen, Waite, \& Ghali, 2016; Rodrigues et al., 2013). The treatment of simple fractures consists of fixation with a $2.0 \mathrm{~mm}$ mini system plate. In complex cases, however, the fixation material must be able to support the load applied to the fracture region, requiring a more resistant fixation system such as the installation of $2.4 \mathrm{~mm}$ mandibular reconstruction plates (García-Guerrero et al., 2018; Miloro et al., 2016). In this case, we opted for open treatment with extraoral access due to the large displacement of the bone stumps and because of the destruction of the tension zone, as there was a need for a more rigid plate 2,4 , we opted for the extra access.

Although rare, this type of complication is associated with one of the most frequently performed procedures in dental offices, thus it is necessary to carry out more prospective studies to attest the best therapeutic approach to this type of occurrence.

\section{Conclusion}

It is concluded that trans or postoperative mandibular fractures are rare complications, however they are likely to happen. To minimize the risks of this complication, in addition to carrying out a good preoperative evaluation, the dental surgeon must carry out a correct planning of the surgical procedure through a thorough analysis of clinical and radiographic examinations and based on the basic principles of the surgical technique. Diagnosis and early treatment of fractures offer better results and minimize complications for the patient. 


\section{References}

Alves Filho, M. E. A., Barreto, J. O., da Silva-Júnior, S. E., Freire, J. C. P., Rocha, J. F., \& Dias-Ribeiro, E. (2019). Estudo retrospectivo das complicações associadas a exodontia de terceiros molares em um serviço de referência no sertão paraibano, Brasil. Archives of Health Investigation, 8(7), 376-380. https://www.researchgate.net/profile/Eduardo-Dias-Ribeiro/publication/336247299_Estudo_retrospectivo_das_complicacoes_associadas_a_exodontia_de _te rc eiro s_molares_em_um_servico_de_referencia_no_sertao_paraibano_Brasil/links/5f4cdce9458515a88b9785bf/Estudo-retrospectivo-das-compl icacoesassociadas-a-exodontia-de-terceiros-molares-em-um-servico-de-referencia-no-sertao-paraibano-Brasil.pdf

Almeida, R. O. P., \& Pereira, B. B. (2020). Relação entre exodontia de terceiros molares e fratura de mandíbula. $R$ Odontol Planal Cent, 19https://dspace.uniceplac.edu.br/bitstream/123456789/488/1/Rodrigo\%20Oliveira\%20Prais\% 20de\%20Almeid a_0007260.pdf

Bachmann, H., Cáceres, R., \& Uribe, C. M. (2014). Complicaciones en Cirugía de Terceros Molares entre los Años 2007ᄀ 2010, en un Hospital Urbano. Int J Odontostomat, 8(1), 107-12.

Bazarin, R., \& Oliveira, R. V. (2018). Acidentes e complicações nas exodontia. Revista Uningá, 55(1), 32-39. http://34.233.57.254 /index.php/uninga/article/view/2102

Blanski, D., Tochetto Primo, B., José Stringhini, D., Luis Barbosa Rebellato, N., João da Costa, D., Scariot de Moraes, R., Roberto Müller, P., \& Eduardo Klüppel, L. (2013). Fratura do corpo da mandíbula após exodontia de $2^{\circ}$ molar inferior em paciente HIV positiva: relato de caso clínico. Revista Da Faculdade De Odontologia - UPF, 17(2). https://doi.org/10.5335/rfo.v17i2.2888

Botelho, T. C. A., de Oliveira Dantas, Á. C., Pimentel, S. M. A., \& Corrêa, A. K. M. (2020). Acidentes e Complicações Associados à Exodontia de Terceiro Molar Inferior Impactado: Revisão de Literatura. Brazilian Journal of Development, 6(12), 96918-96931. https://doi.org/10.34117/bjdv6n12-256

Delantoni, A., \& Antoniades, I. (2010). The iatrogenic fracture of the coronoid process of the mandible. A review of the literature and case presentation. Cranio: the journal of craniomandibular practice, 28(3), 200-204. https://doi.org/10.1179/crn.2010.028

De Lima, V. N., Figueiredo, C. M. B. F., Momesso, G. A. C., de Queiroz, S. B. F., \& Faverani, L. P. (2017). Fratura mandibular associado à remoção de terceiro molar inferior: revisão de literatura. Archives of Health Investigation, 6(9), 414-417. https://www.researchgate.net/profile/Valthierre-DeLima/publication/320210111_Fratura_mandibular_associado_a_remocao_de_terceiro_molar_inferior_revisao_de_literatura/links/59d6dc4e458515db19c5 0613/Fratura-mandibular-associado-a-remocao-de-terceiro-molar-inferior-revisao-de-literatura.pdf

Dos Santos Silva, W., Silveira, R. J., de Araujo Andrade, M., Franco, A., \& Silva, R. F. (2017). Is The Late Mandibular Fracture From Third Molar Extraction a Risk Towards Malpractice? Case Report with the Analysis of Ethical and Legal Aspects. Journal of Oral \& Maxillofacial Research, 8(2), e5. https://doi.org/10.5037/jomr.2017.8205

Ethunandan, M., Shanahan, D., \& Patel, M. (2012). Iatrogenic mandibular fractures following removal of impacted third molars: an analysis of 130 cases. British dental journal, 212(4), 179-184. https://doi.org/10.1038/sj.bdj.2012.135

Flandes, M. P., Dias, L. B. G. M., \& Junior, W. P. (2019). Fratura de mandíbula-relato de caso. Revista de Odontologia da Universidade Cidade de São Paulo, 31(2), 205-212.

García-Guerrero, I., Ramírez, J. M., Gómez de Diego, R., Martínez-González, J. M., Poblador, M. S., \& Lancho, J. L. (2018). Complications in the treatment of mandibular condylar fractures: Surgical versus conservative treatment. Annals of anatomy = Anatomischer Anzeiger,216, 60-68. https://doi.org/10.10 16/j.aanat.2017.10.007

Hupp, J. R., Tucker, M. R., \& Ellis, E. (2015). Contemporary Oral and maxillofacial surgery (6a ed.). Elsevier health sciences.

Ishii, F. T., Negreiros, R. M., Milani, B. A., Bauer, HC, \& Jorge, WA. (2012). Fratura tardia de mandíbula decorrente de exodontia de terceiro molar: relato de caso. Rev Assoc Paul Cir Dent, 66(4), 268-71. http://revodonto.bvsalud.org/scielo.php?script=sci_arttext\&pid=S0004-52762012000400004 $\& \operatorname{lng}=\mathrm{pt} \& \mathrm{nrm}=\mathrm{iso} \& \mathrm{t} \operatorname{lng}=\mathrm{pt}$

Miloro, M., et al. (2016). Princípios de Cirurgia Bucomaxilofacial de Peterson (5a ed.). Santos

Oliveira Soares, L., de Souza Carvalho, B., Gonçalves de Resende, R., \& Martins Gomes, A. (2019). Tratamento fechado em fratura mandibular: parassinfisária e côndilar bilateral - relato de caso clínico. Revista Da Faculdade De Odontologia - UPF, 24(2), 292-298. https://doi.org/10.5335/rfo.v24i2.10457

Pereira, A. S., Shitsuka, D. M., Parreira, F. J., \& Shitsuka, R. (2018). Método Qualitativo, quantitativo ou Quali-Quanti. In Metodologia da Pesquisa Científica. https://repositorio.ufsm.br/bitstream/handle/1/15824/Lic_Computacao_Metodologia-Pesquisa-Cientifica.pdf?sequence=1

Rodrigues, Á. R., Oliveira, M. T. F., Paiva, L. G. J., Rocha, F. S., da Silva, M. C. P., \& Zanetta-Barbosa, D. (2013). Fratura mandibular durante remoção do terceiro molar: fatores de risco, medidas preventivas e métodos de tratamento. Revista Odontológica do Brasil Central, 22(63). https://doi.org/10.3606 5/robrac.v22i63.792

Silva, T., Maranhão Filho, A., Alencar, M., De Bortoli, M. M., \& Vasconcelos, B. (2019). Mandibular fracture after third molar removal: a case report. General dentistry, 67(4), e7-e10. https://pubmed.ncbi.nlm.nih.gov/31355773/

Xu, J. J., Teng, L., Jin, X. L., Lu, J. J., \& Zhang, C. (2014). Iatrogenic mandibular fracture associated with third molar removal after mandibular angle osteotectomy. The Journal of craniofacial surgery, 25(3), e263-e265. https://doi.org/10.1097/SCS.0000000000000566 